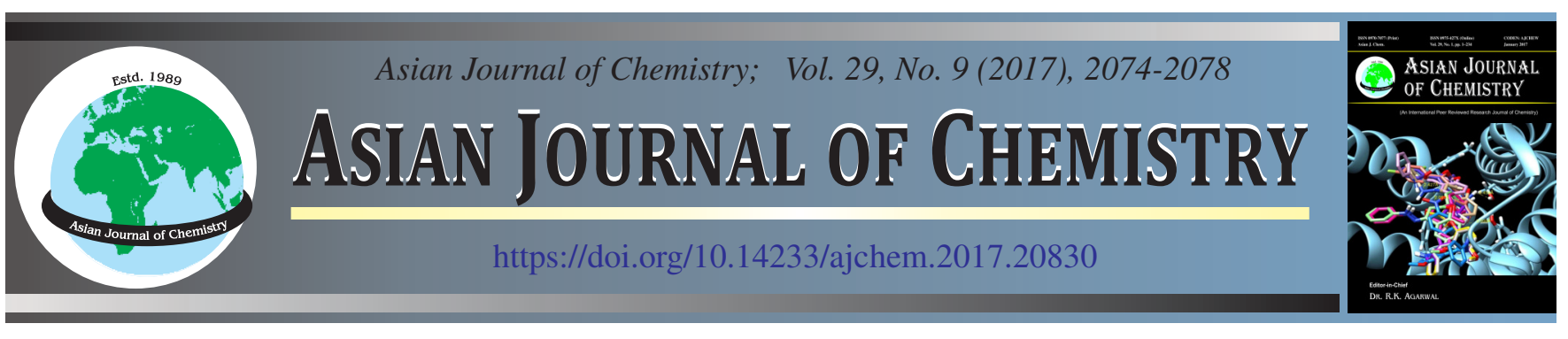

\title{
Design and Synthesis of Novel Fluorescent Phthalimide Based Silatranes: Ratiometric Estimation of $\mathrm{Mg}^{2+} \mathrm{Ion}$
}

\section{GurJaspreet Singh ${ }^{1, *}$, Satinderpal Singh Mangat ${ }^{2}$, Hemant Sharma $^{3}$, JandeEp Singh $^{4}$ and Narinder Singh ${ }^{3, *}$}

\author{
${ }^{1}$ Department of Chemistry, Panjab University, Chandigarh-160 014, India \\ ${ }^{2}$ Dalton Pharma Services, Toronto M4B 1B7, Canada \\ ${ }^{3}$ Department of Chemistry, Indian Institute of Technology Ropar, Rupnagar-140 001, India \\ ${ }^{4}$ Department of Chemistry, Lovely Professional University, Phagwara-144 411, India, India
}

*Corresponding authors: E-mail: gjpsingh@pu.ac.in; nsingh@iitrpr.ac.in

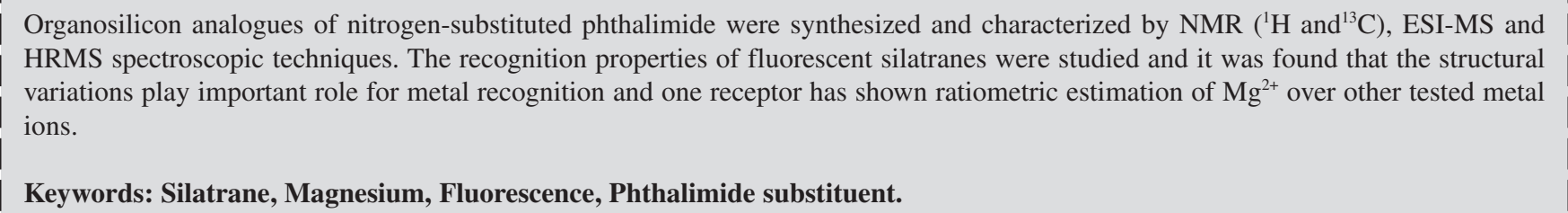

Keywords: Silatrane, Magnesium, Fluorescence, Phthalimide substituent.

\section{INTRODUCTION}

Organosilicon chemistry is considered as the stem of synthesis and structural manipulations of molecules and has gradually undertaken the challenging task of medicine/ biology-oriented synthesis [1-3]. The design and intrinsic properties of organosilicon compounds refuted the prevailing conviction that silicon compounds are biologically inert and incompetent for medical purposes. In recent years, many authors showed interest in organosilicon derivatives of the nitrogen-heterocycles due to their ability to serve as a root for the preparation of series of adsorbents, immobilized catalysts, synthetic intermediates, medicinal drugs, pesticides and other substances endowed with specific biological activities [4-8]. The incorporation of organosilicon substituents into nitrogen heterocycles molecule changes their electronic structure and gives rise to a new class of biological active products, promising for medicinal and agricultural applications [9-17]. Keeping in view the effect of substituent's on the activities, the present manuscript is dealing with the generation of selectivity in the receptors for a particular metal ion. We have demonstrated the genesis of selectivity in a relatively non selective receptor through structural variations around the silicon centre. A nonselective receptor includes the podands, which can offer a number of coordination spheres and thus may fold according to steric requirements of a number of metal ions. Our strategy was mainly concentrated on the fact that our design principally restricts some of the coordination spheres, thus ruling out the possibility for the coordination of a number of metal ions. In our earlier reports, we have demonstrated the origin of selectivity by coating the nonselective podand on the surface of nano-particles [18-21]. The present manuscript deals with the conversion of podands into cryptant like structures and it is a well known fact that cryptands are more selective for a particular metal ion as compared to podands.

\section{EXPERIMENTAL}

The syntheses of silicon derivatives were carried out under dry nitrogen atmosphere with the help of vacuum glass line. The dried organic solvents were used as supplied. N-(Hydroxymethyl)phthalimide (Aldrich) and triethanol amine $\left(\mathbf{L}_{\mathbf{1}}\right)$ (Merck) were used as supplied. Tris(2-hydroxy-3,5-dimethyl-benzyl)amine $\left(\mathbf{L}_{2}\right)$ was prepared according to the published procedure [22]. ${ }^{1} \mathrm{H}$ NMR and ${ }^{13} \mathrm{C}$ NMR spectra were recorded on a Jeol AC 300 FT-NMR spectrometer (DMSO- $d_{6} / \mathrm{CDCl}_{3}$ ). Chemical shifts were reported in ppm relative to $\delta_{\mathrm{H}} 2.49$ for DMSO- $d_{6}$, $\delta_{\mathrm{H}} 7.27$ for $\mathrm{CDCl}_{3}$ and external tetramethylsilane (TMS). Mass spectral measurements (ESI source with capillary voltage, 2500 V) were carried out on a VG Analytical (70-S) spectrometer. HRMS data of unknown compounds was recorded on Waters QQ-TOF micro mass spectrometer. The UV-visible absorption spectra were recorded on a Specord 250 Plus Analytikjena 
spectrometer and Perkin-Elmer L55 fluorescence spectrophotometer were used for fluorescence measurements.

\section{Synthesis of phthalimide derivatives}

Synthesis of N-((triethoxysilyloxy)methyl)phthalimide (1): Chlorotriethoxysilane $(5.60 \mathrm{~mL}, 28.28 \mathrm{mmol}$ ) was added drop-wise at room temperature within $2 \mathrm{~min}$ to a stirred solution of N-(hydroxymethyl)phthalimide (5.00 g, $28.24 \mathrm{mmol}$ ) and triethylamine $(4 \mathrm{~mL}, 28.71 \mathrm{mmol})$ using THF as solvent $(50 \mathrm{~mL})$ under nitrogen atmosphere and the reaction mixture was further stirred for $24 \mathrm{~h}$. The salt of triethylamine formed was filtered off and filtrate was washed thrice with tetrahydrofuran $(3 \mathrm{~mL})$. The solvent (THF) of the filtrate (including the wash solution) was removed in vacuo under reduced pressure resulting into liquid, compound $\mathbf{1}$, as colourless oil. (Yield: $5.80 \mathrm{~g}, 60 \%) .{ }^{1} \mathrm{H} \mathrm{NMR}\left(300 \mathrm{MHz}, \mathrm{CDCl}_{3}\right): \delta 1.12$ (t, $J=3.9$ $\left.\mathrm{Hz}, 9 \mathrm{H}, \mathrm{CH}_{3}\right), 3.78\left(\mathrm{q}, J=6.9 \mathrm{~Hz}, 6 \mathrm{H}, \mathrm{OCH}_{2}\right), 5.33(\mathrm{~s}, 2 \mathrm{H}$, $\mathrm{NCH}_{2}$ ), 7.67 (dd, 2H, Ar-H), 7.75 (dd, 2H, Ar-H); ${ }^{13} \mathrm{C}$ NMR $\left(75 \mathrm{MHz}, \mathrm{CDCl}_{3}\right) \delta 17.51,59.17,60.61,122.96,131.70$, 134.04, 166.90.

\section{Synthesis of phthalimide based silatranes ( 2 and 3 )}

Siltrane 2: In a $100 \mathrm{~mL}$ two-neck round-bottom flask firmly fitted with Dean Stark apparatus, compound 1 (0.93 g, 2.74 $\mathrm{mmol})$ and $\mathbf{L}_{\mathbf{1}}(0.41 \mathrm{~g}, 2.75 \mathrm{mmol})$ were added using dry toluene as reaction solvent $(50 \mathrm{~mL})$. The reaction mixture was then refluxed at $110^{\circ} \mathrm{C}$ for $5 \mathrm{~h}$. The reaction mixture was cooled to room temperature slowly within $60 \mathrm{~min}$. The removal of toluene was carried out under vacuum and slow addition of dry hexane resulted into precipitation of solid. The contents (with hexane) were further stirred for $4 \mathrm{~h}$ at room temperature for complete solid segregation. The solid was filtered and washed twice with dry diethyl ether $(5 \mathrm{~mL})$ and completely dried under vacuum to separate silatrane 2. (Yield: $0.70 \mathrm{~g}, 73 \%)$, m.p. $\left(240{ }^{\circ} \mathrm{C}\right)$. ${ }^{1} \mathrm{H} \mathrm{NMR}\left(300 \mathrm{MHz}, \mathrm{CDCl}_{3}\right): \delta 2.82\left(\mathrm{t}, J=5.7 \mathrm{~Hz}, 6 \mathrm{H}, \mathrm{NCH}_{2}\right)$, $3.67\left(\mathrm{t}, J=5.7 \mathrm{~Hz}, 6 \mathrm{H}, \mathrm{OCH}_{2}\right), 5.13\left(\mathrm{~s}, 2 \mathrm{H}, \mathrm{NCH}_{2}\right), 7.68(\mathrm{dd}$, $2 \mathrm{H}, \mathrm{Ar}-\mathrm{H}), 7.73$ (dd, $2 \mathrm{H}, \mathrm{Ar}-\mathrm{H}) ;{ }^{13} \mathrm{C} \mathrm{NMR}\left(75 \mathrm{MHz}, \mathrm{CDCl}_{3}\right) \delta$ 50.33, 56.74, 61.00, 122.46, 131.74, 133.48, 167.05; MS ( $\mathrm{m} / \mathrm{z}$, assignment): 373 (41.8), 230 (6.2), 216 (14.7), 192 (100), 174 (99.7), 156 (20.8), 116 (8.1), 98 (16.3). HRMS (ES ${ }^{+}$calcd. for $\mathrm{C}_{15} \mathrm{H}_{18} \mathrm{~N}_{2} \mathrm{O}_{6} \mathrm{Si}[\mathrm{M}+\mathrm{K}]^{+}$373.0831, found 373.0845.

Siltrane 3: To the stirred solution of $\mathbf{L}_{2}(1.24 \mathrm{~g}, 2.95 \mathrm{mmol})$ in toluene, catalytic amount of sodium ethoxide was added, in an assembly fitted with dean stark assembly, followed by stirring for $10 \mathrm{~min}$. Compound 1 (1.00 g, $2.94 \mathrm{mmol}$ ) was added drop wise within $2 \mathrm{~min}$ and the reaction mixture was refluxed at $110^{\circ} \mathrm{C}$ for $5 \mathrm{~h}$. The reaction mixture was cooled to room temperature. Toluene was separated under vacuum and on slow addition of dry hexane, precipitated was observed. The contents were further stirred for $4 \mathrm{~h}$ at room temperature. This resulted into light yellowish solid, which was filtered and washed twice with dry diethyl ether $(5 \mathrm{~mL})$ and dried under vacuum to afford the title compound. (Yield: $1.30 \mathrm{~g}, 72 \%$ ), m.p. $\left(280{ }^{\circ} \mathrm{C}\right) .{ }^{1} \mathrm{H}$ NMR $\left(300 \mathrm{MHz}, \mathrm{CDCl}_{3}\right): \delta 2.14\left(\mathrm{~s}, 18 \mathrm{H}, \mathrm{Ar}-\mathrm{CH}_{3}\right), 3.56(\mathrm{~s}$, $\left.6 \mathrm{H}, \mathrm{NCH}_{2}\right), 5.18$ (s, 2H, $\left.\mathrm{OCH}_{2} \mathrm{~N}\right), 6.63$ (s, 3H, Ar-H), 6.77 (s, $3 \mathrm{H}, \mathrm{Ar}-\mathrm{H}$ ), 7.69 (dd, 2H, Ar-H), 7.81 (dd, 2H, Ar-H); ${ }^{13} \mathrm{C}$ NMR $\left(75 \mathrm{MHz} \mathrm{CDCl}_{3}\right) \delta 16.10,19.84,45.42,54.35,117.96,122.83$, $124.92,128.57,129.07,131.47,132.35,133.88,150.91 ; \mathrm{MS}$ (m/z, assignment): 659 (24.1), 16.3 (20.7), 457 (100), 441
(73.0), 419 (27.4), 297 (21.6). HRMS (ES $)$ calcd. for $\mathrm{C}_{36} \mathrm{H}_{36} \mathrm{~N}_{2} \mathrm{O}_{6} \mathrm{Si}[\mathrm{M}+\mathrm{K}]^{+}$659.1979; found 659.1962.

\section{RESULTS AND DISCUSSION}

The chemical synthesis of $\mathrm{N}$-subsituted phthalimide based silatranes was achieved with the aim to convert the podands to crypand, as illustrated in Scheme-I.

As a key intermediate of present designed compounds, compound 1 was synthesized in quantitative yield by reacting $\mathrm{N}$-hydroxy phthalimide with chlorotriethoxysilane. Compound 1 was then refluxed with tripodal ligands $\left(\mathbf{L}_{1}\right)$ and $\left(\mathbf{L}_{2}\right)$ in benzene under anhydrous conditions to afford the target compound $\mathbf{2}$ and $\mathbf{3}$. The chemical structures of synthesized compounds of 1-3 were confirmed by multinuclear $\left({ }^{1} \mathrm{H},{ }^{13} \mathrm{C}\right.$ and ${ }^{29} \mathrm{Si}$ ) NMR, ESI-MS and HRMS spectroscopic techniques. It was noteworthy that ${ }^{1} \mathrm{H}$ NMR spectra of compounds $\mathbf{2 - 3}$ at room temperature were quite different from their parent compound 1, which clearly indicates the presence of silatrane moiety. All protons in the compounds were identified and the total number of protons were calculated from the integration curve. Two equivalent doublets were observed in all cases in the region of 7.67-7.69 and 7.70-7.80 ppm due to phthalimide protons. A triplet and a quartet at 1.12 and $3.77 \mathrm{ppm}$ can be attributed to $\mathrm{CH}_{3}$ and $\mathrm{CH}_{2} \mathrm{O}$ protons of compound 1. Two intense triplets at 2.83 and $3.68 \mathrm{ppm}$ were result of coupling between protons of $\mathrm{OCH}_{2}$ and $\mathrm{NCH}_{2}$ of silatrane moiety. In the ${ }^{13} \mathrm{C}$ NMR of Compound 1, two peaks were observed at 17.5 and 59.1 ppm due to $\mathrm{CH}_{3}$ and $\mathrm{OCH}_{2}$, respectively. Compound 2, peaks observed in region 50.3 and $56.7 \mathrm{ppm}$ were assigned to silatranyl $\mathrm{OCH}_{2}$ and $\mathrm{NCH}_{2}$, respectively. Compound $\mathbf{3}$, aromatic methyl carbons were observed at 16.1 and $19.8 \mathrm{ppm}$. The less shielded carbonyl carbon in all compounds was observed in the region $150.0-167.7 \mathrm{ppm}$. In the ${ }^{29} \mathrm{Si}$ NMR, peaks observed at $\delta-82.7,-96.5 \mathrm{ppm}$ and $-20.91 \mathrm{ppm}$ corresponding to the compound 1, 2 and 3. Mass spectra of final compounds showed peaks correspond to $[\mathrm{M}+\mathrm{Na}]^{+}$or $[\mathrm{M}+\mathrm{K}]^{+}$and their fragmentation pattern resembled with $\mathrm{N}-$ phthalimide. The binding cavity of the receptor for metal ion complexation was established using DFT calculated at the B3LYP/6-31G level (Fig. 1) [23]. As evident from the structure of $\mathbf{1}$, the receptor was devoid of any particular binding cavity. On the other hand the calculated structures of $\mathbf{2 - 3}$ offer a well defined receptor pseudocavity. However, the receptor pseudocavity in receptor $\mathbf{2}$ was comparatively smaller than one obtained from the calculated structure of receptor 3 . A comparison of design of 2-3 lead to conclude that the spacer group between nitrogen and-OH donor sites have an important role to define the size of receptor pseudocavity i.e. in receptor 2 the spacer was alkyl chain $\left(-\mathrm{CH}_{2}-\mathrm{CH}_{2}-\right)$, this spacer was relatively flexible and again may adapt according to the steric requirements of the binding cations, thus much selectivity was not expected from the receptor $\mathbf{2}$. Contrary to this, the receptor $\mathbf{3}$ has rigid spacer (aromatic ring) group and thus a well defined receptor cavity was expected and this will lead to the selective binding of a particular metal ion. The metal recognition studies were carried out in $\mathrm{DMF} / \mathrm{H}_{2} \mathrm{O}(98: 2, \mathrm{v} / \mathrm{v})$ solvent system. The absorption profile of $3(10 \mu \mathrm{M})$ exhibit a band at $\lambda_{\max }=340 \mathrm{~nm}$. On excitation at $\lambda_{\max }=340 \mathrm{~nm}, \mathbf{3}$ showed strong emission at 
<smiles>CCO[Si](Cl)(OCC)OCC</smiles><smiles>CCO[Si](OCC)(OCC)OCN1C(=O)c2ccccc2C1=O</smiles><smiles>OCCN(CCO)CCO</smiles><smiles>O=C1c2ccccc2C(=O)N1CO[Si]12OCCN(CCO1)CCO2</smiles><smiles>CCOc1cc(CN(Cc2cc(C)cc(C)c2O)c2cc(C)cc(C)c2O)c(C)cc1C</smiles><smiles>CCc1cc(C)c(OC)c(CC)c1N[Si](OC)OCN1C(=O)c2ccccc2C1=O</smiles>

Scheme-I: Synthesis of N-phthalimide based silane (1) and silatranes (2 and $\mathbf{3})$

$\lambda_{\max }=432 \mathrm{~nm}$. The cation binding properties of receptor 3 were investigated by changes in its fluorescence behaviour in the presence of various metal ions (Fig. 2A).Interestingly, a red shift in the emission band $\left(\lambda_{\max }=432 \mathrm{~nm}\right)$ of $\mathbf{3}$ was observed on addition of 10 equivalent of $\mathrm{Mg}^{2+}$. However, other metals did not cause any significant change in fluorescence profile of 3. Magnesium is one of the important elements in human body. It acts as co-factor in many cellular processes [24]. It was observed that its deficiency in diet leads to diabetes [25]; therefore endless efforts have been employed to design and synthesis of chemosensors for magnesium sensing [26-28]. However, most of them have poor selectivity due to interference of other ions like $\mathrm{Ca}^{2+}$ and $\mathrm{Ba}^{2+}[29]$. As it was evident from Fig. 2A, that the magnesium binding leads to the shift in the fluorescence intensity of 3. Such recognition may offer the ratiometric fluorescence determination of metal ions. The ratiometric fluorescence determination always have advantage over the monitoring at the single wavelength as the ratiometric determination is free from the errors due to receptor concentration and instrumental errors [30]. To gain more insight about the properties of $\mathbf{3}$ as sensor for magnesium, a titration was performed between 3 and $\mathrm{Mg}^{2+}$ in $\mathrm{DMF} / \mathrm{H}_{2} \mathrm{O}(98: 2$, v/v) solvent system (Fig. 2B).
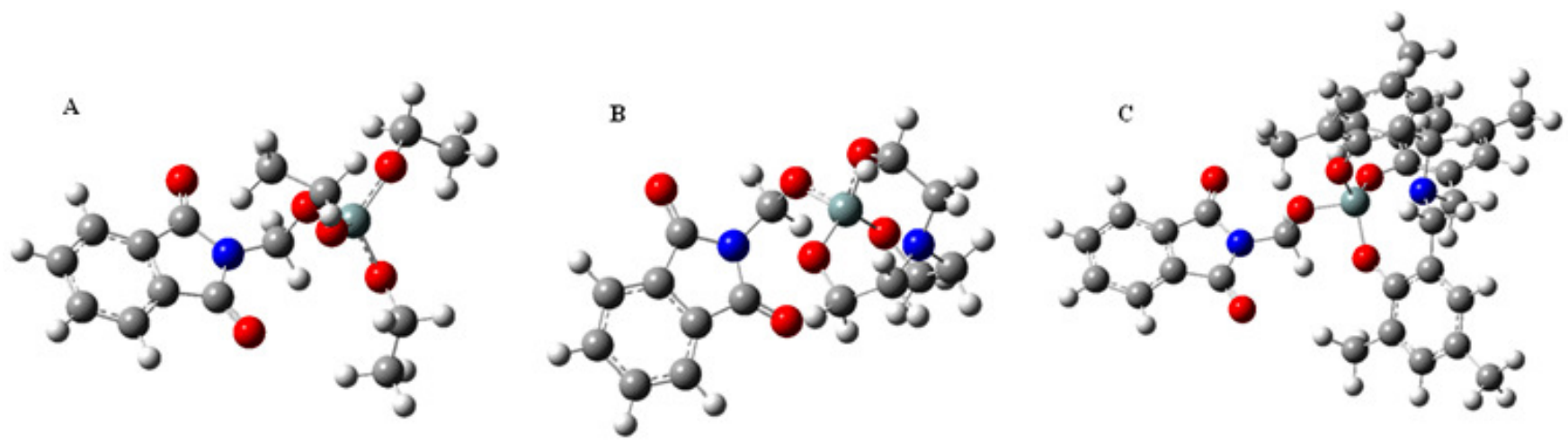

Fig. 1. Energy minimized structure of (A) receptor 1, (B) 2 and (C) 3 calculated at the B3LYP/6-31G level. The red, blue, gray and greenish gary spheres refer to $\mathrm{O}, \mathrm{N}, \mathrm{C}$ and $\mathrm{Si}$ atoms respectively 

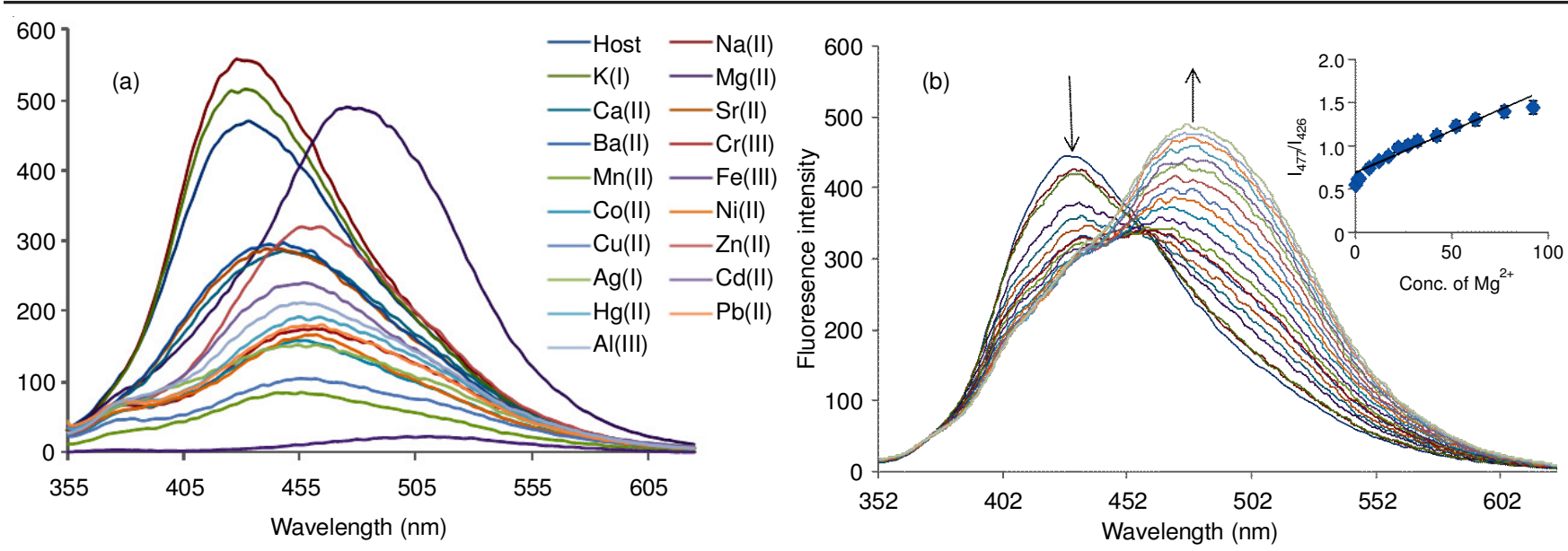

Fig. 2. (A) Changes in fluorescence intensity of $\mathbf{3}(10 \mu \mathrm{M})$ upon addition of $100 \mu \mathrm{M}$ of a particular metal nitrate salt in $\mathrm{HEPES}$ buffered $\mathrm{DMF} / \mathrm{H}_{2} \mathrm{O}(98: 2$, $\mathrm{v} / \mathrm{v}$ ) solvent system (excitation at $340 \mathrm{~nm}$ ); (B) changes in fluorescence spectra of $\mathbf{3}(10 \mu \mathrm{M})$ upon a addition of nitrate salt of $\mathrm{Mg}^{2+}(0-100 \mathrm{mM})$ in HEPES buffered DMF/ $\mathrm{H}_{2} \mathrm{O}(98: 2, \mathrm{v} / \mathrm{v}$ ) solvent system (excitation at $340 \mathrm{~nm}$ ); (Inset of figure showing the ratiometric Fluorescence intensity of $\left(\mathrm{I}_{477} / \mathrm{I}_{426}\right)$ of $\mathbf{3}(10 \mu \mathrm{M})$ against concentration of $\mathrm{Mg}^{2+}(0-100 \mathrm{mM})$ in HEPES buffered DMF/ $\mathrm{H}_{2} \mathrm{O}(98: 2, \mathrm{v} / \mathrm{v})$ solvent system

On continuous addition of $\mathrm{Mg}^{2+}$, a band at $426 \mathrm{~nm}$ was decreased with simultaneously enhancement at $477 \mathrm{~nm}$ and a clear isoemissive point at $460 \mathrm{~nm}$ was observed. The titration curve was plotted and a linear relationship between a ratiometric fluorescence intensity and concentration of $\mathrm{Mg}^{2+}$ was found in range of $(0-100 \mu \mathrm{M})$, as shown in Fig. 2B (inset). These changes in the fluorescence signature of $\mathbf{3}$ were explained on the basis of ICT mechanism. We envisaged that the metal binding close to the fluorophore leads to change the energy gap between the HOMO and LUMO orbitals and thus consequently the shift in fluorescence signature was obtained. The total concentration of receptor 3 and $\mathrm{Mg}^{2+}$ was kept constant with a continuous variable molar fraction of guest $\left(\left[\mathrm{Mg}^{2+}\right] /\right.$ $\left.\left([3]+\left[\mathrm{Mg}^{2+}\right]\right)\right)$. It has maxima at 0.5 which was correspond to 1:1 stoichiometry of complex (Fig. 3A).The Benesi-Hildebrand plot was employed for calculating of association constant $\left(\mathrm{K}_{\mathrm{a}}\right)$ and was found to be $5.2( \pm 0.1) \times 10^{4} \mathrm{M}^{-2}$ (Fig. 3B) [31]. The detection limit was found to be $1.01 \mu \mathrm{M}$. Further, receptors 1 and $\mathbf{2}$ also evaluated through similar procedure for metal binding studies. They did not pronounce any significant change neither in fluorescence spectra nor in UV-visible absorption spectra upon addition of various metal ions. Further, series of competitive titrations were performed to find the limit at which $\mathrm{Mg}^{2+}$ could be measured in the presence of other cations like $\mathrm{Na}^{+}$,
$\mathrm{K}^{+}, \mathrm{Ca}^{2+}, \mathrm{Sr}^{2+}, \mathrm{Ba}^{2+}, \mathrm{Cr}^{3+}, \mathrm{Mn}^{2+}, \mathrm{Fe}^{3+}, \mathrm{Co}^{2+}, \mathrm{Ni}^{2+}, \mathrm{Cu}^{2+}, \mathrm{Zn}^{2+}$, $\mathrm{Ag}^{+}, \mathrm{Cd}^{2+}, \mathrm{Hg}^{2+}, \mathrm{Al}^{3+}, \mathrm{Pb}^{2+}$, etc. It was found that no prominent change in the fluorescence intensity was observed with and without the other cations. It reveals that receptor $\mathbf{3}$ has a high selectivity for $\mathrm{Mg}^{2+}$ over other cations (Fig. 4).

Recognition studies: All studies were performed at room temperature $\left(25 \pm 1{ }^{\circ} \mathrm{C}\right)$ and enough time was provided to solution before recording any spectrum. The cation binding properties of 1-3 were studied by preparing stock solution of 1-3 $(10 \mathrm{mM})$ along with a fixed amounts of particular metal nitrate salt $(50 \mathrm{mM})$ in 4-(2-hydroxyethyl)-1-piperazineethanesulfonic acid (HEPES) buffered in DMF/ $\mathrm{H}_{2} \mathrm{O}(98: 2$, v/v). The changes in fluorescence signature of $\mathbf{1 - 3}$, were used as an indicator of cation binding. The titrations were performed in $10 \mathrm{~mL}$ volumetric flask each containing a stock solution of sensor 1-3 $(10 \mathrm{mM})$ along with different amount of a particular metal salt in HEPES buffered in $\mathrm{DMF} / \mathrm{H}_{2} \mathrm{O}(98: 2$, v/v) solvent system. The stoichiometry of the complex $\left(3, \mathrm{Mg}^{2+}\right)$ was determined by method of continuous variation. The selectivity of sensor $\mathbf{3}$ towards $\mathrm{Mg}^{2+}$ in the presence of other metal ions was confirmed through competitive titrations. The solutions were prepared containing $3(10 \mu \mathrm{M})$ along with fixed concentration of $\mathrm{Mg}^{2+}$ both with and without other interfering metal salts in HEPES buffered in $\mathrm{DMF} / \mathrm{H}_{2} \mathrm{O}(98: 2$, v/v) solvent system.
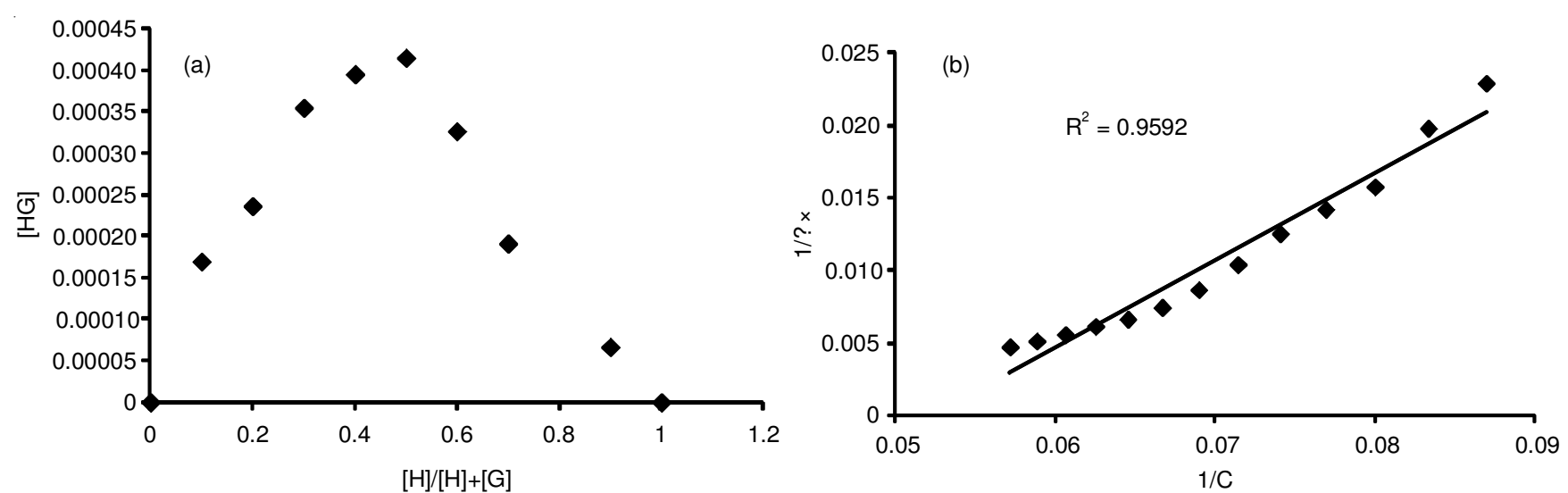

Fig. 3. (A) Job's plot between 3 and $\mathrm{Mg}^{2+}$ showing 1:1 stoichiometry of complex $\left(\mathbf{3}, \mathrm{Mg}^{2+}\right)$. The concentration of [HG] was calculated as $[\mathrm{HG}]=\Delta \mathrm{I} / \mathrm{I}_{\mathrm{o}} \times[\mathrm{H}]$; (B) Benesi-Hildebrand plot for determination of binding constant of complex formed between 3 and $\mathrm{Mg}^{2+}$ 


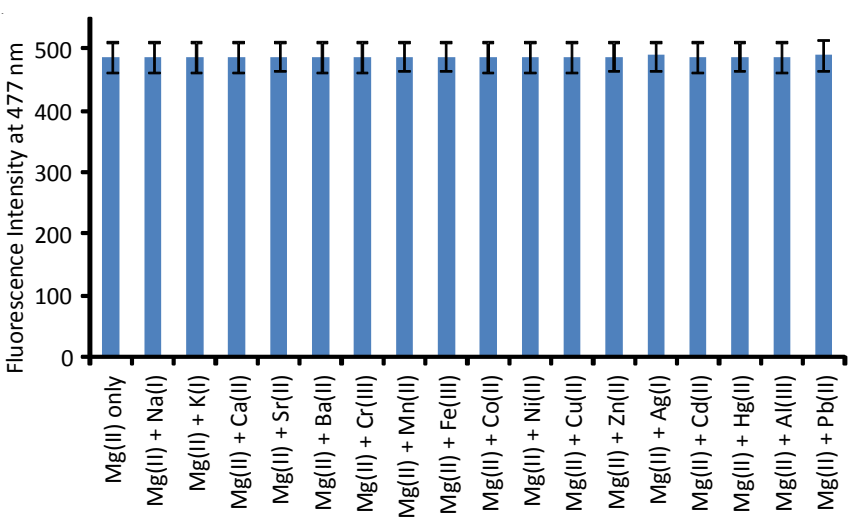

Fig. 4. Estimation of $\mathrm{Mg}^{2+}$ ion by receptor 3 in the presence of other metal ions $\mathrm{Na}^{+}, \mathrm{K}^{+}, \mathrm{Ca}^{2+}, \mathrm{Sr}^{2+}, \mathrm{Ba}^{2+}, \mathrm{Cr}^{3+}, \mathrm{Mn}^{2+}, \mathrm{Fe}^{3+}, \mathrm{Co}^{2+}, \mathrm{Ni}^{2+}, \mathrm{Cu}^{2+}$, $\left.\mathrm{Zn}^{2+}, \mathrm{Ag}^{+}, \mathrm{Cd}^{2+}, \mathrm{Hg}^{2+}, \mathrm{Al}^{3+}, \mathrm{Pb}^{2+}\right)$ in HEPES buffered $\mathrm{DMF} / \mathrm{H}_{2} \mathrm{O}$ $(98: 2, \mathrm{v} / \mathrm{v})$

\section{Conclusion}

A new strategy was implemented to convert the organosilicon derivatives of phthalimide to crypand like supramolecular receptor. The receptor 3 has ratiometric sensing of $\mathrm{Mg}^{2+}$ over other alkali, alkaline and transition metals. It has detection limit of $1.01 \mu \mathrm{M}$ with high selectivity. Further, the binding affinity of these receptors was explained and supported by DFT calculations using B3LYP/6-31G level. It was concluded that structural variations have pivotal role for metal recognition.

\section{ACKNOWLEDGEMENTS}

The authors are thankful to UGC, DST-SERB, DSTPURSE II, New Delhi, India for providing the financial help.

\section{REFERENCES}

1. R. Tacke, T. Heinrich, R. Bertermann, C. Burschka, A. Hamacher and M.U. Kassack, Organometallics, 23, 4468 (2004); https://doi.org/10.1021/om0400671.

2. G. Singh, S.S. Mangat, H. Sharma, J. Singh, A. Arora, A.P. Singh Pannu and N. Singh, RSC Adv., 4, 36834 (2014); https://doi.org/10.1039/C4RA02270J.

3. G. Singh, S.S. Mangat, J. Singh, A. Arora and M. Garg, J. Organomet. Chem., 769, 124 (2014); https://doi.org/10.1016/j.jorganchem.2014.07.014.

4. G. Singh, A. Arora, S.S. Mangat, J. Singh, S. Chaudhary, N. Kaur and D. Choquesillo-Lazarte, J. Mol. Struct., 1079, 173 (2015); https://doi.org/10.1016/j.molstruc.2014.09.042.

5. G. Singh, J. Singh, S.S. Mangat and A. Arora, RSC Adv., 4, 60853 (2014); https://doi.org/10.1039/C4RA08724K.

6. G. Singh, J. Singh, S.S. Mangat and A. Arora, Tetrahedron Lett., 55, 2551 (2014); https://doi.org/10.1016/i.tetlet.2014.03.043.

7. G. Singh, S.S. Mangat, J. Singh, A. Arora and R.K. Sharma, Tetrahedron Lett., 55, 903 (2014);

https://doi.org/10.1016/j.tetlet.2013.12.037.

8. J.K. Puri, R. Singh and V.K. Chahal, Chem. Soc. Rev., 40, 1791 (2011); https://doi.org/10.1039/B925899J.
9. C. Sanchez, B. Julian, P. Belleville and M. Popall, J. Mater. Chem., 15, 3559 (2005); https://doi.org/10.1039/b509097k

10. M. Vallet-Regi, F. Balas and D. Arcos, Angew. Chem. Int. Ed., 46, 7548 (2007); https://doi.org/10.1002/anie.200604488.

11. C.G. Allen, D.J. Baker, J.M. Albin, H.E. Oertli, D.T. Gillaspie, D.C. Olson, T.E. Furtak and R.T. Collins, Langmuir, 24, 13393 (2008); https://doi.org/10.1021/la802621n.

12. J.A. Howarter and J.P. Youngblood, Langmuir, 22, 11142 (2006); https://doi.org/10.1021/la061240g.

13. Z. Jin, X.B. Zhang, D.X. Xie, Y.J. Gong, J. Zhang, X. Chen, G.L. Shen and R.Q. Yu, Anal. Chem., 82, 6343 (2010); https://doi.org/10.1021/ac101305e.

14. A. Zamboulis, N. Moitra, J.J.E. Moreau, X. Cattoën and M.W.C. Man, J. Mater. Chem., 20, 9322 (2010); https://doi.org/10.1039/c000334d.

15. O. De Los Cobos, B. Fousseret, M. Lejeune, F. Rossignol, M. DutreilhColas, C. Carrion, C. Boissière, F. Ribot, C. Sanchez, X. Cattoën, M.W.C. Man and J.-O. Durand, Chem. Mater, 24, 4337 (2012); https://doi.org/10.1021/cm3022769.

16. N. Moitra, J.J.E. Moreau, X. Cattoën and M.W.C. Man, Chem. Commun., 46, 8416 (2010); https://doi.org/10.1039/c0cc03417g

17. V.A. Kuksa, V.A. Pavlov and P.K. Lin, Bioorg. Med. Chem. Lett., 10, 1265 (2000); https://doi.org/10.1016/S0960-894X(00)00201-8.

18. N. Singh, R.C. Mulrooney, N. Kaur and J.F. Callan, Chem. Commun., 40, 4900 (2008); https://doi.org/10.1039/b813423e.

19. H. Sharma, N. Kaur, T. Pandiyan and N. Singh, Sens. Actuators B Chem., 166-167, 467 (2012); https://doi.org/10.1016/j.snb.2012.01.076

20. K. Kaur, N. Kaur and N. Singh, Mater. Lett., 80, 78 (2012); https://doi.org/10.1016/j.matlet.2012.04.043.

21. H. Sharma, K. Narang, N. Singh and N. Kaur, Mater. Lett., 84, 104 (2012); https://doi.org/10.1016/j.matlet.2012.06.066.

22. A. Chandrasekaran, R.O. Day and R.R. Holmes, J. Am. Chem. Soc., 122, 1066 (2000); https://doi.org/10.1021/ja9926360.

23. C. Lee, W. Yang and R.G. Parr, Phys. Rev. B, 37, 785 (1988); https://doi.org/10.1103/PhysRevB.37.785.

24. A. Hartwig, Mutat. Res., 475, 113 (2001); https://doi.org/10.1016/S0027-5107(01)00074-4.

25. M.L. Lima, T. Cruz, L.E. Rodrigues, O. Bomfim, J. Melo, R. Correia, M. Porto, A. Cedro and E. Vicente, Diabetes Res. Clin. Pract., 83, 257 (2009); https://doi.org/10.1016/j.diabres.2008.11.019.

26. P. Bühlmann, E. Pretsch and E. Bakker, Chem. Rev., 98, 1593 (1998); https://doi.org/10.1021/cr970113+.

27. G. Farruggia, S. Iotti, L. Prodi, M. Montalti, N. Zaccheroni, P.B. Savage, V. Trapani, P. Sale and F.I. Wolf, J. Am. Chem. Soc., 128, 344 (2006); https://doi.org/10.1021/ja056523u.

28. Y. Liu, Z.-Y. Duan, H.-Y. Zhang, X.-L. Jiang and J.-R. Han, J. Org. Chem., 70, 1450 (2005); https://doi.org/10.1021/jo047968o.

29. H. Hama, T. Morozumi and H. Nakamura, Tetrahedron Lett., 48, 1859 (2007); https://doi.org/10.1016/j.tetlet.2006.12.147.

30. J.S. Yang, C.Y. Hwang and M.Y. Chen, Tetrahedron Lett., 48, 3097 (2007); https://doi.org/10.1016/j.tetlet.2007.02.120.

31. E. Tomat and S. Lippard, J. Inorg. Chem., 49, 9113 (2010); https://doi.org/10.1021/ic101513a. 